\title{
Commercial Organization
}

National Cancer Institute

\section{Source}

National Cancer Institute. Commercial Organization. NCI Thesaurus. Code C54620.

A for-profit business, including individuals operating commercial enterprises as sole proprietorships, limited and general partnerships, and corporations; or a not-for-profit organization, including private educational and health services institutions, cooperatives, and corporations. 